\title{
Waktu Pulih Sadar pada Pasien Pediatrik yang Menjalani Anestesi Umum di Rumah Sakit Dr. Hasan Sadikin Bandung
}

\author{
Defri Aryu Dinata, ${ }^{1}$ Iwan Fuadi, ${ }^{2}$ Ike Sri Redjeki ${ }^{2}$ \\ ${ }^{1}$ Bagian Anestesi dan Terapi Intensif Rumah Sakit Yadika \\ ${ }^{2}$ Departemen Anestesiologi dan Terapi Intensif \\ Fakultas Kedokteran Universitas Padjadjaran/Rumah Sakit Dr. Hasan Sadikin Bandung
}

\begin{abstract}
Abstrak
Salah satu komplikasi utama pasca-anestesia pada pediatrik adalah keterlambatan pulih sadar. Penyebab keterlambatan pulih sadar pasca-anestesia adalah efek residual dari obat anestetik, sedatif, analgesik, durasi anestesi, dan hipotermia. Penelitian ini bertujuan mengetahui waktu pulih sadar pada pasien pediatrik yang menjalani anestesia umum di Rumah Sakit Dr. Hasan Sadikin Bandung dengan metode penelitian adalah observasional prospektif. Penelitian dilakukan pada bulan Mei-Agustus 2014 dengan sampel sebanyak 456 pasien pediatrik yang menjalani anestesia umum terdiri atas 3,9\% neonatus, $24,6 \%$ infant, $17,3 \%$ batita, dan $54,2 \%$ anak. Parameter yang dicatat pada penelitian ini adalah usia, jenis kelamin, berat badan, jenis anestesia inhalasi, dosis fentanil, durasi anestesia, dan suhu inti tubuh pasca-anestesia. Data penelitian dianalisis secara deskriptif dalam ukuran jumlah dan persentase. Hasil penelitian ini adalah angka kejadian keterlambatan pulih sadar pada pasien pediatrik sebanyak 96 kasus (neonatus 16 kasus, infant 51 kasus, batita 12 kasus, dan anak 12 kasus). Faktor yang memengaruhi waktu pulih sadar pada neonatus adalah hipotermia, pada infant adalah dosis fentanil $>3 \mathrm{mg} / \mathrm{kgBB}$, pada durasi anestesia $>210$ menit dan hipotermia, pada batita adalah hipotermia, dan pada anak adalah dosis fentanil $>5 \mu \mathrm{g} / \mathrm{kgBB}$ dan hipotermia. Simpulan, hipotermia merupakan faktor penyebab keterlambatan waktu pulih sadar pada semua kelompok usia.
\end{abstract}

Kata kunci: Pasca-anestesi, pediatrik, waktu pulih sadar

\section{Recovery Time in Pediatric Patients Undergoing General Anesthesia in Dr. Hasan Sadikin General Hospital Bandung}

\begin{abstract}
The most common causes of prolong awakening are residual effects of drugs either anesthetics, sedatives or analgesics, length of anesthesia, and hypothermia. This study aimed to determine the recovery time to consciousness in pediatric patients undergoing general anesthesia in Dr. Hasan Sadikin General Hospital Bandung. This was an observational prospective study conducted in May until August 2014 on 456 patients consisting of $3.9 \%$ neonates, $24.6 \%$ infants, $17.3 \%$ toddlers and $54.2 \%$ children. Parameters recorded in this study were age, sex, weight, type of inhalation anesthetics, fentanyl dose, duration of anesthesia, and postanesthesia temperature. Data were analyzed descriptively in number and percentage. The results showed that the average recovery time to consciousness in neonatal patients was 50 minutes 40 seconds in which $88.3 \%$ of the neonatal age group suffered from post anesthesia hypothermia (core body temperature below $36^{\circ} \mathrm{C}$ ). Factors that influenced recovery time in infants were fentanyl dose above $3 \mu \mathrm{g} / \mathrm{kgBW}$, duration of anesthesia over 210 minutes, and hypothermia. The factors that caused delayed recovery were hypothermia in toddlers group and fentanyl doses above $5 \mu \mathrm{g} / \mathrm{kgBW}$ and hypothermia in children. Incidence of prolong awakening in pediatric patients undergoing general anesthesia in this study was 96 cases, consisting of 16 cases of neonates, 51 cases of infants, 12 cases of toddlers, and 17 cases of children. In conclusion, the common factor causing delay in recovery in all age groups is hypothermia.
\end{abstract}

Key words: Post-anesthesia, pediatric, recovery time

Korespondensi: Defri Aryu Dinata, dr., SpAn, Bagian Anestesi dan Terapi Intensif Rumah Sakit Yadika, Kompl. Auri Triloka, Jl. Pancoran Barat 9G No. 2A, Pancoran Jakarta Selatan, Mobile 081394404569, Email ro_inmemory@yahoo.com 


\section{Pendahuluan}

Pemulihan dari anestesia umum merupakan saat terjadinya stres fisiologis yang berat pada sebagian besar pasien. Kembalinya kesadaran pasien dari anestesia umum secara ideal harus mulus dan juga bertahap dalam keadaan yang terkontrol. Saat ini, ruang pemulihan tersedia pada sebagian besar rumah sakit di Indonesia. Sebelum itu, banyak terjadi morbiditas serta mortalitas pascaoperasi dini yang sebenarnya dapat dicegah dengan menekankan perawatan khusus segera setelah pembedahan. ${ }^{1}$

Anestesia umum merupakan faktor risiko kasus mortalitas dan morbiditas pada operasi apapun. Kejadian morbiditas serta mortalitas perioperatif lebih tinggi pada anak dibanding dengan pada orang dewasa. ${ }^{2,3}$ Dalam populasi pediatrik, angka morbiditas serta mortalitas perioperatif lebih sering pada neonatus dan bayi dibanding dengan anak yang lebih tua. ${ }^{4,5}$ Bayi benar-benar memiliki risiko morbiditas dan mortalitas yang jauh lebih besar daripada anak yang lebih tua usianya; risiko umumnya berbanding terbalik dengan usia dan neonatus memiliki risiko tertinggi. ${ }^{5}$

Pasien pediatrik bukanlah pasien dewasa yang berukuran kecil. Pediatrik dibagi ke dalam empat kelompok usia, yaitu neonatus $(0-1$ bulan), bayi/infant(1-12 bulan), batita/toddler (1-3 tahun), dan anak-anak (4-12 tahun) yang masing-masing memiliki kebutuhan anestesia yang berbeda. Penatalaksanaan anestesia yang aman bergantung pada penilaian karakteristik fisiologis, anatomis, serta farmakologis dari kelompok masing-masing. ${ }^{5}$ Perbedaan fisik antara dewasa dan anak-anak berkurang pada usia 10 sampai 12 tahun walaupun perbedaan psikologis akan terus berlanjut sampai masa remaja. Kebutuhan obat pada pasien anak berbeda karena ukuran tubuh yang lebih kecil, perbedaan komposisi tubuh, serta kapasitas metabolisme obat. Biasanya dosis didasarkan pada berat badan, hal ini karena berkorelasi erat dengan kompartemen cairan tubuh. ${ }^{1}$

Sebagian besar penelitian yang diterbitkan selama dekade terakhir ini telah melaporkan tingkat morbiditas serta mortalitas pediatrik terkait anestesia kurang dari satu per 10.000 anestesi. ${ }^{2,4,6,7}$ Sebuah penelitian di Brazil telah mengonfirmasi bahwa terjadi nol morbiditas serta mortalitas terkait per 10.000 anestesia. ${ }^{8}$ Berdasarkan hasil studi di atas harus diakui bahwa pada saat ini anestesi umum merupakan tindakan yang aman.

Survei morbiditas serta mortalitas terkait anestesia yang dilakukan di negara-negara berkembang antara tahun 2001 sampai 2011 melaporkan bahwa tingkat morbiditas serta mortalitas terkait anestesia yang tinggi, yaitu 2,4-3,3 per 10.000 anestesia. ${ }^{3}$ Penelitian yang di Nigeria menerangkan bahwa 270 anak yang dijadikan subjek penelitian hanya 65 pasien yang mengalami komplikasi pasca-anestesia dengan tiga pasien mengalami keterlambatan pulih sadar. ${ }^{9}$ Setelah itu, tidak ada penelitian lain yang memublikasikan tentang komplikasi keterlambatan pulih sadar pasca-anestesia pada pasien pediatrik.

Salah satu komplikasi pasca-anestesia pada pasien pediatrik adalah keterlambatan pulih sadar (prolong unconscioussness). ${ }^{9}$ Penanganan yang tidak tepat akan menimbulkan gejala sisa permanen, memperpanjang lama perawatan, serta memberikan efek psikologis yang tidak baik pada pasien pediatrik. ${ }^{10}$

Keterlambatan pulih sadar terjadi ketika pasien gagal mendapatkan kembali kesadaran dalam waktu 30-60 menit setelah anestesia, merupakan efek residual dari obat anestesia, sedatif, serta analgesik. Keterlambatan pulih sadar dapat terjadi sebagai akibat overdosis obat absolut atau relatif atau potensiasi obat anestesia dengan obat lainnya. Kemungkinan penyebab lain adalah hipotermia, gangguan metabolik berat, atau stroke perioperasi. ${ }^{1}$ Keterlambatan pulih sadar yang disebabkan proses organik dikhawatirkan menimbulkan gejala sisa (sekuele) yang harus dikelola dengan tepat. ${ }^{10}$ Penatalaksanaan komplikasi ini adalah dengan mengamankan jalan napas dan juga sirkulasi serta mencari kemungkinan penyebab.

Menurut Mecca, $^{11}$ sekitar $90 \%$ pasien akan kembali sadar penuh dalam waktu 15 menit. Tidak sadar yang berlangsung di atas 15 menit dianggap prolonged, bahkan pasien yang sangat rentan harus merespons stimulus 
dalam 30 hingga 45 menit setelah anestesia. Sisa efek sedasi dari anestesia inhalasi dapat mengakibatkan keterlambatan pulih sadar, terutama setelah prosedur operasi yang lama, pasien obesitas, atau ketika diberikan anestesi konsentrasi tinggi yang berlanjut sampai akhir operasi.

Menurut sebuah studi prospektif terhadap 797 pasien yang telah menjalani operasi besar nonkardiak, terdapat 388 pasien mengalami waktu operasi yang lebih lama dari waktu rata-rata 220 menit dan juga mendapat hasil negatif pascaoperasi. Dari 406 kasus yang durasi anestesianya di atas 240 menit, lima di antaranya mengalami keterlambatan pulih sadar. ${ }^{12}$ Berdasarkan hasil penelitian tersebut diketahui bahwa durasi anestesia ternyata sangat memengaruhi waktu pulih sadar pascaanestesia.

Keterlambatan pulih sadar akan berkurang dengan penggunaan agen berkelarutan rendah seperti sevofluran atau desfluran. Efek sedasi dari opioid intraoperatif atau administrasi obat sedasi berhubungan dengan dosis obat. Opioid dapat menyebabkan sedasi serta bradipnea sehingga opioid dapat memengaruhi tingkat kesadaran pasien. ${ }^{11}$

Tujuan penelitian adalah untuk mengetahui waktu pulih sadar dihubungkan dengan faktorfaktor penyebab terhadap pasien pediatrik yang menjalani anestesia umum di Rumah Sakit Dr. Hasan Sadikin Bandung.

\section{Subjek dan Metode}

Penelitian dilakukan dengan cara prospektif observasional terhadap 456 pasien berusia
1 hari hingga 12 tahun, keadaan sadar penuh sesuai kelompok usia yang akan menjalani operasi menggunakan teknik anestesia umum, dan orangtuanya bersedia anaknya ikut serta dalam penelitian (informed consent). Subjek yang diikutsertakan tidak termasuk dalam kriteria eksklusi, yaitu kelainan sistem saraf pusat dan membutuhkan sedasi dan ventilasi mekanik pasca-anestesi.

Setelah mendapat persetujuan dari Komite Etik Penelitian Kesehatan FK. Unpad/Rumah Sakit Dr. Hasan Sadikin Bandung, pasien yang memenuhi kriteria inklusi didata berdasarkan usia, berat badan, dosis total fentanil, jenis anestesi inhalasi, durasi anestesi, dan suhu inti tubuh pasca-anestesi. Hal yang dinilai adalah waktu ketika obat anestesi terakhir dihentikan hingga pasien mengalami kesadaran sedasi moderat/sedasi sadar, kemudian dilakukan analisis data berdasarkan kelompok usia.

Analisis data penelitian dilakukan memakai analisis univariabel untuk menggambarkan karakteristik subjek penelitian yang meliputi waktu pulih sadar pada setiap kelompok usia serta karakteristik faktor yang kemungkinan adalah sebagai faktor penyebab keterlambatan waktu pulih sadar, yaitu dosis fentanil, jenis anestesia inhalasi, durasi anestesia, dan suhu inti tubuh pasca-anestesia. Data dianalisis secara deskriptif dalam ukuran jumlah serta persentase untuk data kategorik.

\section{Hasil}

Penelitian dilakukan terhadap 456 pasien yang terdiri atas neonatus, infant, batita, serta anak. Jumlah pasien terbanyak adalah anak

Tabel 1 Karakteristik Umum Penelitian

\begin{tabular}{lccccc}
\hline & Total & Neonatus & Infant & Batita & Anak \\
\hline Jumlah (n,\%) & $456(100 \%)$ & $18(3,9 \%)$ & $112(24,6 \%)$ & $79(17,3 \%)$ & $247(54,2 \%)$ \\
Berat badan kg & $14,1 \pm 8,4 ;$ & $3,2 \pm 1,3 ;$ & $5,0 \pm 2,2 ;$ & $9,96 \pm 3,58 ;$ & $20,3 \pm 6,0 ;$ \\
(Mean $\pm S D$, range) & $2,2-46$ & $1,3-8,1$ & $2,2-18$ & $3,5-19$ & $6-46$ \\
Jenis kelamin & & & & & \\
$\quad$ Laki-laki (n,\%) & $242(53,1 \%)$ & $12(66,6 \%)$ & $58(51,8 \%)$ & $36(45,6 \%)$ & $136(55,1 \%)$ \\
$\quad$ Perempuan (n,\%) & $214(46,9 \%)$ & $6(33,4 \%)$ & $54(48,2 \%)$ & $43(54,4 \%)$ & $111(44,9 \%)$ \\
\hline
\end{tabular}


dengan rentang berat badan seluruh sampel penelitian 2,2-46 kg. Jumlah pasien laki-laki lebih banyak dibanding dengan perempuan (Tabel 1).

Semua pasien neonatus memakai anestesia inhalasi sevofluran. Pasien yang diberikan dosis fentanil lebih dari $3 \mu \mathrm{g} / \mathrm{kgBB}$ mengalami keterlambatan pulih sadar terlama dengan rata-rata 71 menit 20 detik. Waktu pulih sadar terkecil terlihat pada durasi anestesia $<120$ menit dan terlama pada durasi anestesia $>240$ menit. Baik hipotermia ataupun normotermia mengakibatkan keterlambatan waktu pulih sadar. Waktu pulih sadar terlama terjadi pada hipotermia (Tabel 2).

Pada pasien infant, waktu pulih sadar ratarata terhadap pemberian anestesia inhalasi isofluran lebih singkat bila dibanding dengan sevofluran. Terdapat keterlambatan waktu pulih sadar pada pemberian fentanil di atas 3 $\mu \mathrm{g} / \mathrm{kgBB}$, yaitu 39 menit 32 detik, sedangkan pada durasi anestesia di atas 210 menit terjadi keterlambatan waktu puih sadar dengan lama waktu rata-rata 39 menit 17 detik. Selain itu, pada suhu hipotermia, waktu pulih sadar lebih lama dibanding dengan suhu normotermia (Tabel 3).

Pada pasien batita, baik anestesia inhalasi isofluran atau sevofluran tidak menyebabkan ketelambatan waktu pulih sadar. Tidak ada pasien yang diberikan dosis fentanil lebih dari 5 $\mu \mathrm{g} / \mathrm{kgBB}$. Durasi anestesia tidak menyebabkan keterlambatan pada waktu pulih sadar dengan waktu pulih sadar terlama terlihat pada durasi anestesi lebih dari 180 menit. Suhu hipotermia mengakibatkan keterlambatan waktu pulih sadar dengan rata-rata 33 menit 9 detik (Tabel 4).

Terdapat pasien yang diberikan fentanil lebih dari $5 \mu \mathrm{g} / \mathrm{kgBB}$ dengan waktu pulih sadar 72 menit. Waktu pulih sadar rata-rata terkecil terlihat pada durasi anestesia kurang dari 60 menit dan terbesar pada durasi anestesia lebih dari 180 menit. Keterlambatan pulih sadar terlihat pada suhu hipotermia dengan ratarata 35 menit 44 detik (Tabel 5).

Kejadian keterlambatan pulih sadar pasien pediatrik yang menjalani anestesia umum di Rumah Sakit Dr. Hasan Sadikin Bandung pada bulan Mei-Agustus 2014 sebanyak 96 kasus

Tabel 2 Waktu Pulih Sadar pada Pasien Neonatus

\begin{tabular}{|c|c|c|c|}
\hline Faktor Penyebab & $\begin{array}{l}\text { Rentang } \\
\text { (menit) }\end{array}$ & $\begin{array}{c}\text { Meann士SD } \\
\text { (' menit, " detik) }\end{array}$ & $\underset{n}{\text { Jumlah }}$ \\
\hline \multicolumn{4}{|l|}{ Anestesi inhalasi } \\
\hline Sevofluran & $21-72$ & $50^{\prime} 40^{\prime \prime} \pm 16^{\prime} 12^{\prime \prime}$ & 18 \\
\hline Isofluran & Tidak ada data & Tidak ada data & \\
\hline \multicolumn{4}{|l|}{ Dosis fentanil $(\mu \mathrm{g} / \mathrm{kgBB})$} \\
\hline $1-3$ & $21-66$ & $46^{\prime} 24^{\prime \prime} \pm 14^{\prime} 25^{\prime \prime}$ & 15 \\
\hline $3,1-5$ & $70-72$ & $71^{\prime} 20^{\prime \prime} \pm 1^{\prime} 9^{\prime \prime}$ & 3 \\
\hline$>5$ & Tidak ada data & Tidak ada data & \\
\hline \multicolumn{4}{|l|}{ Durasi anestesi (menit) } \\
\hline$<120$ & $25-45$ & $37^{\prime} 15^{\prime \prime} \pm 9^{\prime} 19^{\prime \prime}$ & 4 \\
\hline $120-180$ & $21-56$ & $42^{\prime} \pm 16^{\prime} 45^{\prime \prime}$ & 4 \\
\hline $181-240$ & $32-70$ & $55^{\prime} 40^{\prime \prime} \pm 14^{\prime} 48^{\prime \prime}$ & 6 \\
\hline$>240$ & $52-72$ & $65^{\prime} 15^{\prime \prime} \pm 9^{\prime} 26^{\prime \prime}$ & 4 \\
\hline \multicolumn{4}{|l|}{ Suhu pascaoperasi } \\
\hline Hipotermia & $32-72$ & $53^{\prime} 20^{\prime \prime} \pm 13^{\prime} 37^{\prime \prime}$ & 12 \\
\hline Normotermia & $21-66$ & $37^{\prime} 20^{\prime \prime} \pm 24^{\prime} 54^{\prime \prime}$ & 6 \\
\hline
\end{tabular}


Tabel 3 Waktu Pulih Sadar pada Pasien Infant

\begin{tabular}{|c|c|c|c|}
\hline Faktor Penyebab & $\begin{array}{l}\text { Rentang } \\
\text { (menit) }\end{array}$ & $\begin{array}{c}\text { Mean } \pm \text { SD } \\
\text { (' menit, " detik) }\end{array}$ & $\begin{array}{l}\text { Jumlah } \\
\text { n (\%) }\end{array}$ \\
\hline \multicolumn{4}{|l|}{ Anestesi inhalasi } \\
\hline Sevofluran & $4-74$ & $28^{\prime} 12^{\prime \prime} \pm 15^{\prime} 33^{\prime \prime}$ & $64(57,1 \%)$ \\
\hline Isofluran & $8-78$ & $27^{\prime} 46^{\prime \prime} \pm 15^{\prime} 7^{\prime \prime}$ & $48(42,9 \%)$ \\
\hline \multicolumn{4}{|l|}{ Dosis fentanil ( $\mu \mathrm{g} / \mathrm{kgBB})$} \\
\hline $1-3$ & $4-78$ & $24^{\prime} 4^{\prime \prime} \pm 13^{\prime} 30^{\prime \prime}$ & $84(75,0 \%)$ \\
\hline $3,1-5$ & $15-74$ & $39^{\prime} 32^{\prime \prime} \pm 13^{\prime} 55^{\prime \prime}$ & $26(23,2 \%)$ \\
\hline$>5$ & $44-65$ & $54^{\prime} 30^{\prime \prime} \pm 14^{\prime} 51^{\prime \prime}$ & $2(1,8 \%)$ \\
\hline \multicolumn{4}{|l|}{ Durasi anestesi (menit) } \\
\hline$<90$ & $8-35$ & $19^{\prime} 47^{\prime \prime} \pm 8^{\prime} 55^{\prime \prime}$ & $23(20,5 \%)$ \\
\hline $90-150$ & $8-78$ & $26^{\prime} 10^{\prime \prime} \pm 13^{\prime} 5^{\prime \prime}$ & $38(33,9 \%)$ \\
\hline $151-210$ & $4-70$ & $25^{\prime} 55^{\prime \prime} \pm 15^{\prime} 1^{\prime \prime}$ & $26(23,2 \%)$ \\
\hline$>210$ & $12-74$ & $39^{\prime} 17^{\prime \prime} \pm 16^{\prime} 7^{\prime \prime}$ & $25(22,4 \%)$ \\
\hline \multicolumn{4}{|l|}{ Suhu pascaoperasi } \\
\hline Hipotermia & $15-78$ & $42^{\prime} 23^{\prime \prime} \pm 15^{\prime} 28^{\prime \prime}$ & $37(33,1 \%)$ \\
\hline Normotermia & $4-42$ & $21^{\prime} 12^{\prime \prime} \pm 9^{\prime} 28^{\prime \prime}$ & $75(66,9 \%)$ \\
\hline
\end{tabular}

yang sebagian besar terjadi pada kelompok usia infant sebanyak 51 kasus. Keterlambatan waktu pulih sadar berdasarkan kelompok usia, persentase yang terbesar terjadi pada neonatus, yaitu 88,9\% dan terkecil pada anak, yaitu 6,9\% (Tabel 6).

Tabel 4 Waktu Pulih Sadar pada Pasien Batita

\begin{tabular}{lccc}
\hline \multicolumn{1}{c}{ Faktor Penyebab } & $\begin{array}{c}\text { Rentang } \\
\text { (menit) }\end{array}$ & $\begin{array}{c}\text { Mean } \pm \text { SD } \\
\text { (' menit, " detik) }\end{array}$ & $\begin{array}{c}\text { Jumlah } \\
\text { n (\%) }\end{array}$ \\
\hline Anestesi inhalasi & & & \\
$\quad$ Sevofluran & $5-55$ & $21^{\prime} 18^{\prime \prime} \pm 9^{\prime} 52^{\prime \prime}$ & $41(52 \%)$ \\
$\quad$ Isofluran & $5-72$ & $21^{\prime} 6^{\prime \prime} \pm 13^{\prime} 25^{\prime \prime}$ & $38(48 \%)$ \\
Dosis fentanil ( $\mu \mathrm{g} / \mathrm{kgBB})$ & & & \\
$\quad 1-3$ & $5-45$ & $17^{\prime} 7^{\prime \prime} \pm 8^{\prime} 29^{\prime \prime}$ & $52(66 \%)$ \\
$3,1-5$ & $8-72$ & $28^{\prime} 58^{\prime \prime} \pm 13^{\prime} 32^{\prime \prime}$ & $27(34 \%)$ \\
$>5$ & Tidak ada data & Tidak ada data & Tidak ada data \\
Durasi anestesi (menit) & & & \\
$<60$ & $5-21$ & $11^{\prime} 56^{\prime \prime} \pm 5^{\prime} 14^{\prime \prime}$ & $17(21 \%)$ \\
$60-120$ & $5-36$ & $20^{\prime} 15^{\prime \prime} \pm 8^{\prime} 6^{\prime \prime}$ & $16(20 \%)$ \\
$121-180$ & $8-45$ & $20^{\prime} 43^{\prime \prime} \pm 8^{\prime} 21^{\prime \prime}$ & $41(32 \%)$ \\
$>180$ & $8-72$ & $29^{\prime} 52^{\prime \prime} \pm 15^{\prime} 28^{\prime \prime}$ & $21(27 \%)$ \\
Suhu pascaoperasi & & & \\
$\quad$ Hipotermia & $15-72$ & $33^{\prime} 9^{\prime \prime} \pm 16^{\prime} 29^{\prime \prime}$ & $13(16 \%)$ \\
$\quad$ Normotermia & $5-45$ & $18^{\prime} 48^{\prime \prime} \pm 9^{\prime} 8^{\prime \prime}$ & $66(84 \%)$ \\
\hline
\end{tabular}


Tabel 5 Waktu Pulih Sadar pada Pasien Anak

\begin{tabular}{lccc}
\hline \multicolumn{1}{c}{ Faktor Penyebab } & $\begin{array}{c}\text { Rentang } \\
\text { (menit) }\end{array}$ & $\begin{array}{c}\text { Mean } \pm \text { SD } \\
\text { (' menit, " detik) }\end{array}$ & $\begin{array}{c}\text { Jumlah } \\
\text { n (\%) }\end{array}$ \\
\hline Anestesi inhalasi & & & \\
$\quad$ Sevofluran & $5-75$ & $17^{\prime} 17^{\prime \prime} \pm 10^{\prime} 31^{\prime \prime}$ & $111(44,9 \%)$ \\
$\quad$ Isofluran & $5-100$ & $17^{\prime} 19^{\prime \prime} \pm 12^{\prime} 25^{\prime \prime}$ & $136(55,1 \%)$ \\
Dosis fentanil ( $\mu \mathrm{gg} / \mathrm{kgBB})$ & & & \\
$\quad 1-3$ & $5-100$ & $15^{\prime} 7^{\prime \prime} \pm 9^{\prime} 43^{\prime \prime}$ & $187(75,7 \%)$ \\
$3,1-5$ & $8-75$ & $23^{\prime} 17^{\prime \prime} \pm 12^{\prime} 46^{\prime \prime}$ & $59(23,9 \%)$ \\
$>5$ & 72 & $72^{\prime}$ & $1(0,4 \%)$ \\
Durasi anestesi (menit) & & & \\
$<60$ & $5-65$ & $13^{\prime} \pm 8^{\prime} 17^{\prime \prime}$ & $60(24,3 \%)$ \\
$60-90$ & $5-28$ & $14^{\prime} \pm 4^{\prime} 52^{\prime \prime}$ & $65(26,3 \%)$ \\
$91-180$ & $5-100$ & $18^{\prime} 28^{\prime \prime} \pm 12^{\prime} 53^{\prime \prime}$ & $71(28,8 \%)$ \\
$>180$ & $5-75$ & $24^{\prime} 52^{\prime \prime} \pm 15^{\prime} 52^{\prime \prime}$ & $51(20,6 \%)$ \\
Suhu pascaoperasi & & & \\
$\quad$ Hipotermia & $15-75$ & $35^{\prime} 44^{\prime \prime} \pm 17^{\prime}$ & $23(9,3 \%)$ \\
$\quad$ Normotermia & $5-100$ & $15^{\prime} 23^{\prime \prime} \pm 8^{\prime} 58^{\prime \prime}$ & $224(90,7 \%)$ \\
\hline
\end{tabular}

\section{Pembahasan}

Sebagian besar neonatus yang telah menjalani operasi memakai anestesia umum di Rumah Sakit Dr. Hasan Sadikin Bandung mengalami keterlambatan pulih sadar dan juga penurunan suhu tubuh yang sangat besar. Waktu pulih sadar pasien akan lebih lama sebanding dengan peningkatan dosis fentanil. Peningkatan dosis fentanil akan menyebabkan peningkatan kadar fentanil di dalam plasma level sehingga akan memperpanjang durasi kerja fentanil. ${ }^{5,13}$ Selain

Tabel 6 Jumlah Kasus Keterlambatan Waktu Pulih Sadar

\begin{tabular}{lcc}
\hline $\begin{array}{c}\text { Kelompok } \\
\text { Usia }\end{array}$ & $\begin{array}{c}\text { Jumlah } \\
\text { Kasus } \\
\text { (f) }\end{array}$ & $\begin{array}{c}\text { Persentase } \\
\text { Setiap } \\
\text { Kelompok } \\
\text { Usia (\%) }\end{array}$ \\
\hline Neonatus & 16 & 88,9 \\
Infant & 51 & 45,5 \\
Batita & 12 & 15,2 \\
Anak & 17 & 6,9 \\
\hline Jumlah & 96 & 21,05 \\
\hline
\end{tabular}

itu, peningkatan dosis fentanil juga sangat berhubungan dengan durasi operasi. Operasi yang berlangsung lama akan membutuhkan dosis fentanil yang semakin tinggi (Tabel 2).

Struktur sawar darah otak pada neonatus yang belum sempurna menyebabkan fentanil dapat menembus sawar darah otak dengan sangatmudah danjuga setelahitu, menurunkan sensitivitas kemoreseptor batang otak pada karbondioksida dengan konsekuensi depresi pernapasan sehingga terjadi hiperkapnia. Hal ini dapat memengaruhi clearance agen anestesi inhalasi dan karbondioksida, keduanya dapat memperlama waktu pulih sadar. ${ }^{10}$

Durasi anestesia yang lama dihubungkan dengan paparan anestesia inhalasi yang lama pula. Pemulihan kesadaran pada pasien dari anestesia inhalasi bergantung pada eliminasi pulmonal yang akan ditentukan oleh ventilasi alveolar, co-efisien partisi darah-gas, dan dosis minimum alveolar concentration (MAC-hour). Hipoventilasi alveolar akan memperpanjang waktu yang dibutuhkan untuk mengeluarkan anestesia inhalasi sehingga menunda waktu pemulihan. Durasi yang diperlukan untuk 
sadar akan lebih lama sesuai dengan lamanya durasi anestesia, akan tetapi tidak mengubah $\mathrm{MAC}_{\text {awake }}$. Penggunaan anestesia inhalasi yang lama akan mengakibatkan waktu pulih sadar memanjang. ${ }^{10}$

Waktu pulih sadar pada neonatus dengan durasi anestesia lebih dari 240 menit menjadi memanjang, yaitu 65 menit 15 detik (Tabel 2). Hasil ini sesuai dengan penelitian sebelumnya bahwa durasi anestesia di atas 240 menit akan memengaruhi lama waktu pulih sadar. Dapat disimpulkan bahwa durasi anestesia sangat memengaruhi hasil akhir operasi serta waktu pulih sadar pasca-anestesia. ${ }^{12}$

Pada hasil penelitian ini terjadi penurunan suhu yang cukup tinggi pada neonatus, keadaan ini kemungkinan besar disebabkan neonatus memiliki rasio luas permukaan tubuh dengan berat badan yang lebih besar, dengan sedikit lemak subkutan sehingga menjadi lebih mudah kehilangan panas. ${ }^{5}$ Waktu pulih sadar terhadap neonatus yang mengalami hipotermia lebih lama bila dibanding dengan neonatus yang normotermia. Hal ini disebabkan hipotermia dapat mengakibatkan penurunan metabolisme obat. ${ }^{14,15}$ Hipotermia mengubah efek banyak golongan obat, termasuk obat pelemas otot, anestesi inhalasi, dan obat anestesi intravena. ${ }^{16}$ Aliran darah hati serta ginjal akan berkurang dengan hipotermia ringan yang kemudian menurunkan metabolisme serta ekskresi obat, dengan resultan penurunan plasma clearance dan juga peningkatan efek obat. ${ }^{17} \mathrm{Hal}$ ini dapat menimbulkan efek durasi obat anestesia akan memanjang sehingga pulih dari pengaruh obat anestesia akan lebih lama.

Waktu pulih sadar infantyang menggunakan anestesia inhalasi sevofluran adalah 28 menit 12 detik, sedangkan dengan anestesia inhalasi isofluran adalah 27 menit 46 detik (Tabel 3). Hasil ini menunjukkan bahwa kelompok yang menggunakan anestesi inhalasi isofluran lebih cepat waktu pulih sadarnya dibanding dengan kelompok sevofluran. Secara teoritis waktu induksi dan juga pulih akan lebih cepat dengan mempergunakan sevofluran. ${ }^{18}$ Hasil penelitian tersebut dengan teori sangatbertolak belakang. Hal ini dapat saja disebabkan beberapa faktor seperti ketidakseragaman dosis fentanil yang diberikan, perbedaan durasi dan suhu pascaanestesia, ataupun faktor-faktor lainnya.

Pada penelitian ini terjadi keterlambatan waktu pulih sadar terhadap kelompok yang mendapatkan fentanil 3,1-5 $\mu \mathrm{g} / \mathrm{kgBB}$ yaitu 39 menit 32 detik dan dosis fentanil di atas $5 \mu \mathrm{g} / \mathrm{kgBB}$ yaitu 54 menit 30 detik (Tabel 3). Hal ini disebabkan peningkatan dosis fentanil akan meningkatkan kadar fentanil dalam level plasma sehingga akan memperpanjang durasi kerja fentanil., ${ }^{5,13}$ Selain itu, tidak terdapat perbedaan mencolok secara fisiologis antara neonatus dan infant.

Waktu pulih sadar terhadap durasi anestesi 151 sampai 200 menit adalah 25 menit 55 detik, lebih cepat dibanding dengan kelompok durasi anestesia 90 hingga 150 menit, yaitu 26 menit 10 detik (Tabel 3). Secara teori hal ini juga sangat tidak sesuai, kemungkinan disebabkan ketidakseragaman dosis fentanil yang diberikan, perbedaan durasi serta suhu pasca-anestesia, atau faktor-faktor lain. Terjadi keterlambatan waktu pulih sadar berdasarkan durasi anestesia pada penelitian ini, yaitu pada durasi anestesia di atas 210 menit dengan waktu pulih sadar selama 39 menit 17 detik. Sesuai dengan penelitian sebelumnya bahwa durasi anestesia dapat memberikan hasil yang negatif pasca-anestesia dan juga memengaruhi waktu pulih sadar pasca-anestesi. ${ }^{12}$

Suhu pasca-anestesia sangat memengaruhi waktu pulih sadar pada infant, terlihat bahwa pada suhu hipotermia terjadi keterlambatan waktu pulih sadar selama 42 menit 23 detik, sedangkan pada keadaan normotermia tidak terjadi keterlambatan pada waktu pulih sadar. Waktu pulih sadar pada pasien batita dengan mempergunakan anestesia inhalasi sevofluran adalah 21 menit 18 detik, sedangkan dengan anestesia inhalasi isofluran adalah 21 menit 6 detik. Hasil ini menunjukkan bahwa kelompok yang menggunakan anestesia inhalasi isofluran mempunyai waktu pulih sadar yang lebih cepat dibanding dengan kelompok sevofluran. Secara teoritis, waktu induksi dan pulih akan lebih cepat dengan menggunakan sevofluran. ${ }^{18}$ Hasil penelitian ini sangat bertolak belakang dengan teori. Hal ini dapat saja terjadi yang kemungkinan besar disebabkan oleh beberapa 
faktor seperti ketidakseragaman dosis fentanil yang diberikan, durasi anestesi, dan juga suhu pasca-anestesia, ataupun faktor lain (Tabel 4).

Pada kelompok usia batita, waktu pulih sadar menjadi semakin lama seiring dengan bertambahnya dosis fentanil, durasi anestesia, dan penurunan suhu tubuh, walaupun secara fisiologi kelompok usia batita dan anak hampir menyerupai fisiologi pasien dewasa.

Dalam penelitian ini, pasien batita dengan suhu hipotermia pasca-anestesia mengalami keterlambatan pada waktu pulih sadar dengan lama waktu 33 menit 9 detik (Tabel 4). Hal ini juga disebabkan oleh efek dari hipotermia yang menyebabkan metabolisme obat menjadi turun. $^{14,15}$ Penelitian ini menyatakan bahwa anestesiainhalasibaikpada sevofluran maupun isofluran tidak mengakibatkan keterlambatan waktu pulih sadar terhadap anak. Faktor yang mengakibatkan keterlambatan waktu pulih sadar anak adalah dosis fentanil lebih dari 5 $\mu \mathrm{g} / \mathrm{kgBB}$, dengan waktu pulih sadar 72 menit (Tabel 5). Anak mempunyai komposisi cairan yang berbeda bila dibanding dengan neonatus. Neonatus memerlukan dosis yang lebih besar untuk menghasilkan efek yang sama dengan anak dikarenakan neonatus memiliki volume distribusi yang lebih besar. ${ }^{19}$ Pada dosis besar, yaitu di atas $5 \mu \mathrm{g} / \mathrm{kgBB}$ yang diberikan pada anak akan memengaruhi waktu pulih sadar pasca-anestesia.

Hipotermia menjadi salah satu penyebab keterlambatan waktu pulih sadar pada anak. Pada suhu hipotermia waktu pulih sadar pada anak adalah 35 menit 44 detik (Tabel 5). Hal ini disebabkan oleh metabolisme agen anestesia melambat akibat hipotermia. ${ }^{14-17}$

Terdapat dua orang pasien anak mengalami waktu pulih lambat yang disebabkan oleh end stage renal disease (ESRD), walaupun pasien diberikan fentanil dosis rendah dengan durasi anestesi yang singkat serta suhu inti pasca-anestesia yang normal. Keadaan ini disebabkan gangguan ekskresi fentanil oleh ginjal sehingga efek sedasi fentanil menjadi memanjang.

Angka kejadian keterlambatan pulih sadar pasca-anestesi pada pasien neonatus dan infant yaitu $88,9 \%$ dan $45,5 \%$, lebih tinggi daripada kelompok usia lainnya (Tabel 6). Sesuai dengan teori dan penelitian sebelumnya bahwa angka morbiditas serta mortalitas perioperatif lebih sering pada neonatus dan infant bila dibanding dengan kelompok yang lebih tua, dikarenakan oleh perbedaan karakteristik fisiologis yang mencolok bila dibandingkan dengan kelompok usia lain. ${ }^{5}$ Perbedaan fisiologis pada neonatus dan infant dibanding dengan kelompok usia yang lebih tua adalah sawar darah otak yang belum matang sehingga obat-obatan anestesia terutama fentanil yang dapat menembus sawar darah otak dengan sangat mudah. ${ }^{10}$ Perbedaan lainnya adalah fungsi hati yang belum matang sehingga dapat menurunkan fungsi enzim hati dan biotransformasi obat-obatan anestesia. ${ }^{3,13}$ Selain itu, rasio luas permukaan tubuh yang lebih besar pada berat badan dengan sedikit lemak subkutan akan lebih mudah kehilangan panas dan mengalami hipotermia. ${ }^{5}$

\section{Simpulan}

Berdasarkan hasil penelitian dan pembahasan dapat dirumuskan simpulan bahwa hipotermia merupakan faktor penyebab keterlambatan waktu pulih sadar pada semua kelompok usia.

\section{Daftar Pustaka}

1. Butterworth JF, Mackey DC, Wasnick JD. Postanesthesia care. Dalam: Morgan GE, Mikhail M, penyunting. Clinical anesthesiology. Edisi ke-5. New York: McGraw Hill; 2013. hlm. 1257-75.

2. Flick RP, Sprung J, Harrison TE, Gleich SJ, Schroeder DR, Hanson AC, dkk. Perioperative cardiac arrests in children between 1988 and 2005 at a tertiary referral center: a study of 92,881 patients. Anesthesiology. 2007;106(2):226-37.

3. Bharti N, Batra YK, Kaur H. Paediatric perioperative cardiac arrest and its mortality: database of a 60-month period from a tertiary care paediatric centre. Eur J Anaesthesiol. 2009;26(6):490-5.

4. Van der Griend BF, Lister NA, McKenzie IM, Martin N, Ragg PG, Sheppard SJ, dkk. Postoperative mortality in children after 
101,885 anesthetics at a tertiary pediatric hospital. Anesth Analg. 2011;112(6):1440 $-7$.

5. Butterworth JF, Mackey DC, Wasnick JD. Pediatric anesthesia. Dalam: Morgan GE, Mikhail M, penyunting. Clinical anesthesiology. Edisi ke-5. New York: McGraw Hill; 2013. hlm. 877-905.

6. Murat I, Constant I, Maud'huy H. Perioperative anaesthetic morbidity in children: a database of 24,165 anaesthetics over a 30-month period. Paediatr Anaesth. 2004;14(2):158-66.

7. Ahmed A, Ali M, Khan M, Khan F. Perioperative cardiac arrests in children at a university teaching hospital of a developing country over 15 years. Paediatr Anaesth. 2009;19(6):581-6.

8. Braz LG, Braz JR, Mo'dolo NS, do Nascimento P, Brushi BA, Carvalho LR. Perioperative cardiac arrest and its mortality in children. A 9-year survey in a Brazilian tertiary teaching hospital. Paediatr Anaesth. 2006; 16(8):860-6.

9. Edomwonyi NP, Ekwere IT, Egbekun R, Eluwa B. Anesthesia-related complications in children. MEJ Anesth. 2006;18(5):915.

10. Sinclair R, Faleiro R. Delayed recovery of conciousness after anaesthesia: contin Educ Anaesth Crit Care Pain. 2006;6(3): 114-8.

11. Mecca RS. Postoperative recovery. Dalam: Barash PG, Cullen BF, Stoelting RK, penyunting. Clinical anesthesia. Edisi ke7. Philadelphia: Lippincott Williams \& Wilkins; 2013. hlm. 1380-405.

12. Gordon NA, Koch ME. Duration of anesthesia as an indicator of morbidity and mortality in office-based facial plastic surgery. A review of 1.200 consecutive cases. Arch Facial Plast Surg. 2006;8:4753.

13. Macfarlane F. Pediatric anatomy and physiology and the basic of pediatric anaesthesia. Anaesthesia UK [diunduh 6 Oktober 2006]. Tersedia dari: http://www. frca.co.uk/article.aspx?articleid=100544.

14. Bissonnette B, Sessler DI. Mild hypothermia does not impair postanesthetic recovery in infants and children. Anesth Analg. 1993; 76(1):168-72.

15. Lenhardt R, Marker E, Goll V, Tschernich H, Kurz A, Sessler DI, dkk. Mild intraoperative hypothermia prolongs postanesthetic recovery. Anesthesiology. 1997;87(6): 1318-23.

16. Leslie K, Sessler DI, Bjorksten AR, Moayeri A. Mild hypothermia alters propofol pharmacokinetics and increases the duration of action of atracurium. Anesth Analg. 1995;80(5):1007-14.

17. Heler T, Caldwell JE, Sessler DI, Miller RD. Mild intraoperative hypothermia increases duration of action and spontaneous recovery of vecuronium blockade during nitrous oxide-isoflurane anesthesia in humans. Anesthesiology. 1991;74(5):815 -9 .

18. Butterworth JF, Mackey DC, Wasnick JD. Inhalation anesthetics. Dalam: Morgan GE, Mikhail M, penyunting. Clinical anesthesiology. Edisi ke-5. New York: Mc Graw Hill; 2013. hlm. 153-73.

19. Skinner A. Paediatric pharmacology: Bristol Royal Hospital for Children. Bristol. (diunduh 2 Januari 2014). Tersedia dari: http://www.aagbi.org/sites/default/ files/48-Paediatric-pharmacology1.pdf. 